\title{
IMPACT OF COORDINATION FOR ORGANIZATION PROCESS
}

\author{
Ramūnas VANAGAS \\ Mykolas Romeris University, Vilnius \\ E-mail: rvanagas@mruni.eu \\ Janina STANKEVIČ \\ Mykolas Romeris University, Vilnius
}

doi:10.13165/IE-14-8-2-08

\begin{abstract}
The article analyzed the organization of work: work organization and its constituent elements studied in theoretical aspect. It is also presented organization, the division of labor, organizational structures, hierarchy, the concept of coordination and their values in organization activity. The discussed measures, in organizations of public and private sector, should help organize the staff work. Purified the importance of the coordination in the organization of work and discussed the principal regulations, elements and features of the practical application. With the development of technology and science, work organization problems remain continuously relevant because the organization of tools and methods should change and improve parallel. Summarizing the theoretical data, at the end of the article the authors compare them with the results of an empirical study performed in Vilnius district municipality in 2013 and presents the conclusions.
\end{abstract}

\section{JEL classification: D2.}

Keywords: coordination, organization, the division of labor.

\section{Introduction}

Many organizations try to introduce the most successful system, which would lead to successful performance. The scientific literature also often analyzed elements of the 
organization of work, but the lack of the particularity in examining the measures, which would help to organize the work of staff. Therefore, this article tries to perform a systematic analysis of the process of work organization.

In the nineteenth-century organization and management aspects in the written sources began to analyse M. Bolton, W. Brown, B. Gott and other scientists. Their studies provided organizational features of various companies and their application in other companies. However, founder of the organization's management system is considered to be F. Taylor (1880), in his work "Principles of Scientific Management" stated that the management is based on the correct work organization for workers and leaders and presented work organization features. F. Taylor was followed by H. Gantt, F. and L. Gilbreths and H. Emerson, who formulated 12 principles of performance, staying still relevant today.

H. Ford revised and adapted to practice the theory of scientific organization. From the beginning of "Ford T" production (1908) until 1927 he propagated mass production, therefore in his own factories he organized work in accordance with the principles of productivity. Meanwhile M. Weber (1890) talked about the theory of ideal bureaucratic management, which aims - to regulate the organization of activity strictly by rules, standards and instructions.

In the same period, the theoretical foundations of organizational activity formulated $\mathrm{H}$. Fayol (1898). He formulated the general cycle of management functions and clarified 14 administration principles in detail, which should be followed in all of the management functions. Analyzing Fayol administrative activity cycle, L. Gulick (1913) provided his own distribution of administrative activities and called it POSDCORB, which compared with H. Fayol, distinguished the role of leadership. L. Gulick together with L. Urwick (1915) developed a theory of organizational structures, provided principles of units specialization, one of the first examined the categories of duties, rights and delegated responsibilities. Significantly contributed to the theory of administrative activities of the organization Lithuanian V. Graičiūnas (1915), who mathematically based the empirical formula of controllability rate and proved that the optimal quantity of the subordinate staff for the leader is 4-6.

M. P. Follett and E. Mayo in the third decade of the twentieth century developed the theory of human relations. M. Follett has put a lot of work in the development of various management theories, although in this theory he presented his thoughts disorderly and illogically and also did not summarize the conclusions. Compared with M. Follett, an American scientist E. Mayo, this theory explained in a much more integrated and systematic way.

Analysing social relationships, the researchers realized that the reasons which motivate people to work better must be clarified. In 1943 appeared A. Maslow's hierarchy of human needs. He stated that there are five levels of human needs: physiological, safety, communication, respect and recognition, and self-expression, while the motivation was investigated by F. Herzberg, D. McGregor, R. Likert, C. Argyris, W. Bennis and others (1950). 
R. Falk's and W. Newman's (1961) principles of the activity organization are widely distributed. However, there is no systematic material, which would combine and provide organizational elements, as well as their performance measurement model.

The problem of activity organization is relevant to each organization, as one or other chosen organizational method has a direct influence on activity results. In order to improve performance, leaders should focus on the organization of work elements and measures. Therefore, the organization of work should be a priority action, which is focused on the organization's employees' motivation, skills, growth of productivity and flexibility, functional, useful and effective work. Thus, the aim of this article is to figure out the coordination features of the process of work organization.

Article object - the process of organization.

Raised problems:

- Discuss the features of work organization in theoretical terms.

- Identify the function of coordination in work organization process.

- Compare the results of the empirical investigation with theoretical insights.

\section{The main elements of work organization}

In the opinion of various foreign and Lithuanian authors, the organization can be characterized as an establishment of commitment, mandates, distribution of functions and subordination between members of organization. It was described very similarly by Stoner et al. (2005), Little (2012), Лукичёва (2007), claiming that this was a process during which work is divided, the structural units, and hierarchy are formed, mechanisms for coordination of activity are created. "An organization is an inclusion of two or more people to work together in the certain structure, seeking for the particular purpose or purposes as a whole. An organization is the process of the division of labor, authority, and resources among the organization's members and their adaptation, which allows them to achieve organizational goals. This is a permanent management process, which forms and keeps the organizational structure" (Paunskiene, Antanaviciene, Peleckis, 2011, page 89).

B. Neverauskas and J. Rastenis (2001) claims that during the process of organization the companies create and further improve the structures, which enable people to work along and effectively by achieving company's goals, and have two main aspects: the reconciliation of mandates and arrangement of organization departments.

Marcinkevičiūte and Žukovskis (2007) stated that "organization is the development of system structure, which includes employees' relationships, rights, duties, goals, functions, activities and other factors affecting when employees share a common work". Although Misevičius (2010) identified it as a creation of required system to achieve the determined goals, where the main task is the division of the company's personnel into certain groups and hierarchical arrangement of these groups. "Work organization is a management of the work structure process in the production process, the human interaction between themselves and human interaction with the equipment and working facilities" (Vanagas, 2009, p. 30). In other 
authors' opinion, "organization is a formation of the structure, which predisposes an efficient work for achieving the goals. It is an elaboration of prepared plan realization, setting and adjustment of the functions of activities, limits of liability, resources, terms; transferring (delegation) of the rights and responsibilities (tasks) to the employee or department, which becomes responsible for their performance (Stoškus, Beržinskienè, 2005, p. 121).

According to Melville (2011), Васильев (2007), Schreyögg (2007), Stoner et al. (2005), Paunskienè, Antanavičienè, Paleckis (2011), the content of organization activity consists of the following main elements:

- The division of labor - such a complex task is splitting into components that employees are responsible not for the entire task, but for the different activities. This is the optimal distribution of the whole work into separate parts and identification of specific performers.

- Formation of structural units is a grouping of the similar and logically related operating activities into the structural element. In order to see how the work is distributed, leaders create the organizational schemes of the management structures. This is a determination of composition and connection between employees and departments.

- Hierarchy - a model of many organizational structure levels, on top of which is a top-level manager (or managers) responsible for all activities of the organization; others, the lower-level managers, are located on different lower levels of organizational management. It's a creation of a certain number of management levels.

- Coordination - a process of combining the organization's goals and the inevitable specialization, which comes with the division of labor and formation of chains. Coordination refers to the establishment of communication channels between people who are executing different work. Coordination is intended to correct the executors' actions, which do not comply with the selected course of the plan.

In the aforementioned organizational elements of this article prevail these activity measures:

$>$ Detalization, specification, regulation of actions (processes, operations), provided in the plan (work planning, job evaluation, extension, enrichment, ergonomics);

$>$ Work grouping by functions, processes, products, customers, geographical location (branches), time (shifts);

$>$ Anticipation, selection of employees for detailed and regulated operations, detailed specification of their position, familiarization with their duties and operations ${ }^{1}$;

Anticipation of communication and subordination between employees (OMS setting of control rate, i.e. number of employees directly reporting to the Head manager, and

${ }^{1}$ The authors will compare further analyze the data obtained with the 2012 carried out empirical research in the following article. 
management chains, i.e. team chains, visible to any organization in the organizational management structure);

Division of responsibilities between managers, managing the implementation of the plan (centralization, decentralization, delegation, i.e. a formal grant of authority to a subordinate to carry out certain activities, which are not included in the work description);

$>$ Preparation of control systems of plan realization (of procedure, methods, process), using basic control mechanisms - the hierarchy, rules, procedures.

Similar measures of activity organization have been described by other authors: Papšienė (2010), Peters (2005), Ruegg - Sturm (1994) and Simon (2000).

Meanwhile, Bakanauskas et al. (2011) understood the organization as a work, management and resources allocation to members of the organization and their coordination, which allows achieving the goals of the organization. During this process the authority is distributed, formal roles of organization members are named, divisions are created, which are linked by certain contacts and relationships, tasks and functions are divided between all the elements, responsibility, authority and rights are taken within the organization, reflecting the centralization and decentralization ratio while managing the company.

In conclusion, it can be said that the organization is one of the factors of effective work. The organization in whole consists of an amount of everyday work, which is determined by each employee. Therefore, while organizing, it is important to specify the job of each employee, and provide him with authority. Only with structured work distribution and the existence of accurate management system and position identification, an organization can exist as a successfully working entity.

\section{Coordination function in the context of work organization}

To achieve the objective, a detailed analysis of the coordination function will be carried out, as one of the parts of the organization. Undoubtedly, it can be said that the coordination is the process of integration of individual parts of the organization's activity to achieve common goals (Bakanauskas et al., 2011, p. 278). But it must not be forgotten that it is often considered that coordination is like the addition to the division of labor. This is not true, because when work is distributed, division and break-up of tasks happens, while coordination is an integration of tasks; many opinions are found in the literature, that coordination is the opposite process of the division of labor. This means that coordination combines together workers with different but interrelated work tasks in order to achieve the organizational goals.

It is important for everyone to realize that while coordinating it is necessary to align all company's operations so that the company would gain success as soon as possible, proportionally reconcile certain things and activities and to adapt certain measures to achieve the objectives. A famous control theory classic Fayol (1898) agreed with this idea. 
Bea F. X. and Haas, J. (2005), Ginevičius, Sūdžius (2008), Bakanauskas et al. (2011) identified the causes that give rise to the need for coordination:

- The division of labor and specialization;

- Individual attitude differences between employees that hinder to find concordant solutions, working methods, styles, or time;

- Staff relationships, when communication between employees and managers is ineffective: it is insufficient; there is no feedback or non-constructive conflict;

- Limited resource allocation problems when different departments have to share the same resources at the same time or in turn in order to utilize them more effectively.

The identification of these reasons and their effective use in organization management leads to better results. As stated by Bea F. X. and Haas J. (2005), coordination is essential to directing the activity of all members of the organization towards the main objectives of the organization.

More broadly, coordination is a universal function because it belongs to general management functions (planning, control, organization, motivation and other). Programs are created during planning, which determine the coordination methods and tools.

In other words, while organizing an activity, managers coordinate the whole work broken down into smaller operations, through job instructions, schedules, procedures, specifications or other documents governing the work results. This means that managers are responsible for the fluency of the activity coordination process, they motivate employees so that actions be coordinated with one another, that the division of labor and specialization of tasks splitted into the objectives be achieved, assigned tasks be performed in cooperation due to physical, psychological, cognitive and other personal limitations (Bakanauskas et al., 2011).

Choi and Y. Hong (2002), Seifert (2003), Martinkus, Stoškus, Beržinskienè (2010) and other authors distinguish four coordination modes: interaction, standardization of work procedures, standardization of qualifications and quality norms. According to them, the best way of coordination and communication is an interaction when there are no standardized rules. Application of work procedure standardization is guided by specially developed job procedures descriptions, work processes governing documents. Performing a specialist training process and organizing his evaluation or before accepting to work, the essential employee knowledge and skill level is highlighted; it is coordination through standardization of qualifications. It is important to understand that the work can be coordinated in various ways. To achieve this goal, the simplest way of coordination - mutual adaptation, when several commonly working participants, equally understanding the meaning and content of their work, select and carry out the necessary steps to succeed by themselves. This means that all work participants should have developed abilities to operate the workflow properly if the procedure deviates and to make fruitful actions, if given the chance to produce a better product. 
Another way of work coordination is a direct instruction - what needs to be done is specified by a person who oversees the whole procedure and knows all the potential participants' actions and each one's potential (Butkus, 2008 p. 25).

Danese P. (2005), Bakanauskas et al. (2011) provide a broader and more frequently encountered in the scientific literature coordination form list:

- Personal instruction coordinated bureaucratic systems, where a vertical hierarchy relation exists;

- Group coordination: committees, conferences, negotiations and other forms of communication, as well as the organizational culture as a collective phenomenon (values, norms, attitudes, etc. acceptable in the organization);

- Team coordination is based on the team members' initiative and specially created team organization units that follow team activity methods;

- Settlement systems also coordinate the actions of employees: if an employee knows that he will earn more if he reaches certain performance results or does a certain job, he will try to achieve this by coordinating his actions according to the pursuing results;

- Formal documents: work instructions, standards, procedures, rules, codes, etc.;

- Activity is coordinated within established organizational management structures by special programs to solve complex problems, managing them with special programs, for which created special coordinating bodies and a detailed plan of step coordination.

The application of forms of coordination depends on the frequency of their occurrence. If the problem is a one-off, it will be enough the head of personnel instruction verbal or written order. This method is simpler and faster to implement, but it is not appropriate when a problematic situation persists. In case to save the manager's time, repetitive actions are described in the procedures, standards, and rules. This form of coordination is longer lasting and requires special knowledge, skills and experience in creating action plans and programs. Choosing between a group and a team form of coordination, there are important forms of coordination factors such as formal or informal which is related to communication and self-determination, violence, flexibility and adaptation to environmental changes speed. In order to enhance the human potential, it is better suited for a group and a team forms of coordination. Some scientists argue that the best way to ensure the proper performance of the duties is meetings of the heads of departments. At each meeting, the heads of departments report on how the work is underway, what difficulties are encountered, and what help should be needed. After a discussion, the manager makes a decision. The purpose of the meetings is to facilitate the implementation of the action plan, to ensure cooperation between departments, inform managers about the company's activities.

According to T. Choi and Y. Hong (2002), management in certain structures implies an existence of certain coordination system, the purpose of which is to coordinate and synchronize actions of organizations that forming a network. P. Danese (2005) identifies a coordination mechanism as an organization and synchronizing of all members' actions of the networks in all processes between these organizations. T. Malone (1987) understands an interorganizational coordination as the decision-making and communication principles to the 
general objectives of the network implementation. Correctly understanding, the system of coordination within the organization is an entire of actions, tools and channels of communication that allows to combine all of the relationships between network elements, structures, processes and to manage them holistically in order to achieve the objectives agreed in advance.

The successful activity of the organization depends on the division of labor into separate tasks between employees and these employees coordination. Regardless of how the works will be separated and designed, of how the delegation of authority works, the common activity of several people must be coordinated, to each member of the organization must be clear who does what. Employee while working with other employees must coordinate its actions with coworkers and to carry out instructions of managers.

In summary, the coordination is an element of organization which seeks to ensure the subjects, objects and working processes of the interaction between time and space limits. In specialization time, all the staff works are distributed, and each organizational unit performs the tasks assigned to him. Coordination is important for the fact that subdivided tasks would be directed to the purpose of the organization; that would be a clear coherence between the sharing and coordination. That is why coordination is an important and significant element of the organization.

\section{An empirical study of partial results ${ }^{2}$}

Certain tasks are assigned to each workplace. Tasks, authority, and responsibilities are specified in each employee's duties instruction. The description of duties is one of the documents that help managers to coordinate all the entire work process. Therefore, in drawing up the tasks description, the scientists recommend following certain principles. Administration applies compliance, indicators, the uniformity of sanctions and incentive, work priorities, sufficient detail and self-expression principles by preparing works descriptions and designing workplaces (Fig. 1.). $77 \%$ of employees' work meets the physical and mental capabilities; $20 \%$ meets partly, and $3 \%$ does not comply at all. This means that $23 \%$ of employees assigned to do too much or too complex tasks and thus the matching principle is violated. The study showed that $100 \%$ of employees are familiar with their work duties description. Only $46 \%$ of all tasks are performed in employees' duties instruction. 52 $\%$ not all tasks are performed in respondents' duties instruction and it may mean that those employees have to perform tasks belonging to another workplace. $2 \%$ some additional tasks

${ }^{2}$ All study data by authors will be published in other scientific articles. The study was conducted in Vilnius district administration in November of 2012. In order to reflect the results of the survey respondents' opinion about with a probability of $95 \%$ and $5 \%$ of the selected error there should be involved 138 respondents (in municipal administration worked 214 employees). The study involved 156 respondents. The study was applied questionnaire, interviews and document analysis. Data processing and preparation of illustrations have been used in the Microsoft Excel program. The study selected an anonymous questionnaire which consisted of 19 closed-ended and one open question. 
which they do not perform are described in employees' duties instruction. These figures show that the preparation of duty instructions for each individual work place does not comply with a principle of sufficient detail.

Infringement of indicators principle shows that workers are not entirely clear which indicators are evaluated on the basis of whether the work is performed. $51 \%$ of respondents replied that the indicators which are evaluated their work are clear to them, $32 \%$ partially clear and $17 \%$ not at all clear (Fig. 1.). Thus, only half of the respondents strongly know what indicators are based on an assessment of their work.

Figure 1. The application of the principles of the task description of Vilnius district municipality administration (percentage distribution)

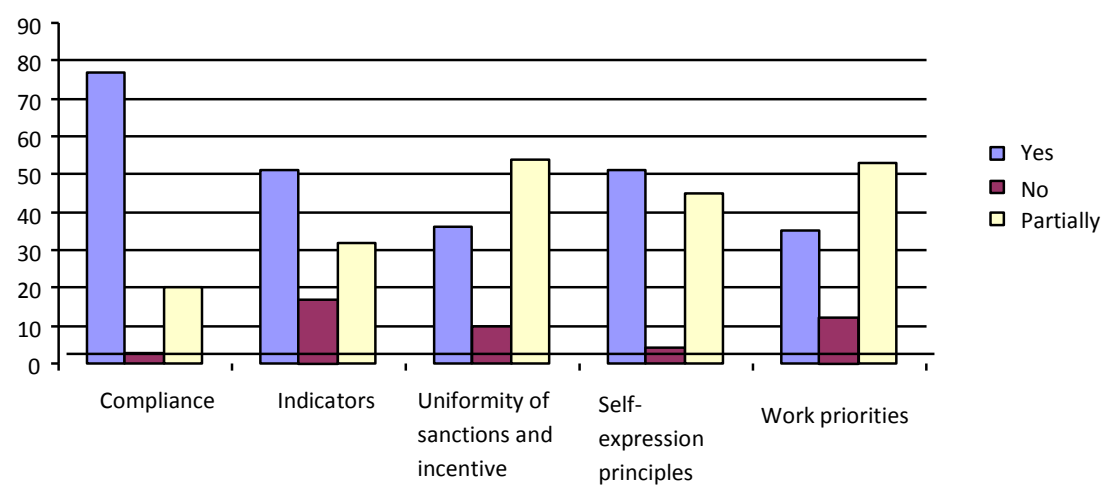

In the description of the work, it is necessary to refer to incentives and sanctions otherwise known as the incentives and penalties, the principle of uniformity. Works should be described and assessed equally detailed because workers tend to perform more specific tasks. Analysis of the questionnaire shows that only $36 \%$ of employees' work is detailed and clearly described. Therefore, the employment of labor can be impossible to measure and punish deviations. Therefore, employees' work may be impossible to assess and punish deviations (54\% partially and $10 \%$ not at all). The significance of the work is indicated in $35 \%$ of employees' work descriptions and in $12 \%$ not at all clear which work is more important, which should be given the most attention. $53 \%$ of employees partially know which work is a priority and can differently interpret the significance of the work aspect. $51 \%$ of respondents' work corresponds to their abilities and interests provide opportunities for self-expression, 45 $\%$ meets partly and $4 \%$ do not meet at all. The possibility of self-expression increases employee motivation and therefore it is important that the position would provide opportunities for self-expression. The possibility of expression is granted only half of the 
employees in the municipality. This means that other employees are less motivated, and their place of work does not provide an opportunity to use knowledge and skills.

In order that the subdivision would be successful it is necessary to prepare and validate department regulations. Each subdivision member must be familiar with the regulations of the department. Establishing the subdivision has to be clear why that department is necessary, what indicators will be assessed in its work, what are its features, rights, responsibilities and communication with other departments. During the investigation found out that $80 \%$ of respondents are familiar with their regulations of the department. $14 \%$ of them have not heard about such a document. $3 \%$ argues that the regulations are approved, but the employees are not familiar with them, and $3 \%$ said that the regulations of the department have not been approved.

A department regulation is management and coordination tool. Therefore, managers should ensure that each department has approved regulations and familiarized the staff with them.

Respondents, who indicated that they are aware of department regulations, have been asked to evaluate regulations parts by score from 1 to 5 (1-low, 5-high), based on their completeness and clarity. From the 1 table, it is visible that all regulation parts were evaluated similarly, but none of them 100 percent scored 5. It means that department regulation parts are not clearly defined, or staff is not fully familiarized with them, some of the department staff doesn't know the departments' purpose, functions, rights and responsibilities, which could have negative impact on the overall work of the organization.

Table 1. Vilnius district Municipality, administrations staff evaluation of its department regulations parts (percent)

\begin{tabular}{|l|l|l|l|l|l|l|}
\hline Sr. no. & Department regulations parts & 1 & 2 & 3 & 4 & 5 \\
\hline 1. & Department purpose & 4 & 2 & 2 & 28 & 64 \\
\hline 2. & Department performance & 4 & 8 & 16 & 31 & 41 \\
\hline 3. & Department main functions & 4 & 2 & 4 & 28 & 62 \\
\hline 4. & Department rights & 6 & 2 & 15 & 27 & 50 \\
\hline 5. & Department responsibilities & 2 & 2 & 8 & 26 & 62 \\
\hline 6. & Department connection with other dep & 4 & 8 & 18 & 31 & 39 \\
\hline
\end{tabular}

Analysis of the survey results has revealed that work in Municipality is specialized, feedback and communication are weak, and these are just a few reasons why it requires the regulation of the performance. Scientists state that the best way of coordination is cooperation 
between the staff. In this way, 5 percent of respondents coordinate their actions (fig. 2). Thus, performance is coordinated by part of the senior and chief specialist. Standardization of work procedures and the coordination of individual orders scored 22 percent. Even 51 percent of respondents indicated, that their performance is coordinated by all of the three ways mentioned above.

Figure 2. Performance coordination methods in Vilnius district municipality administration according to the post (percent)

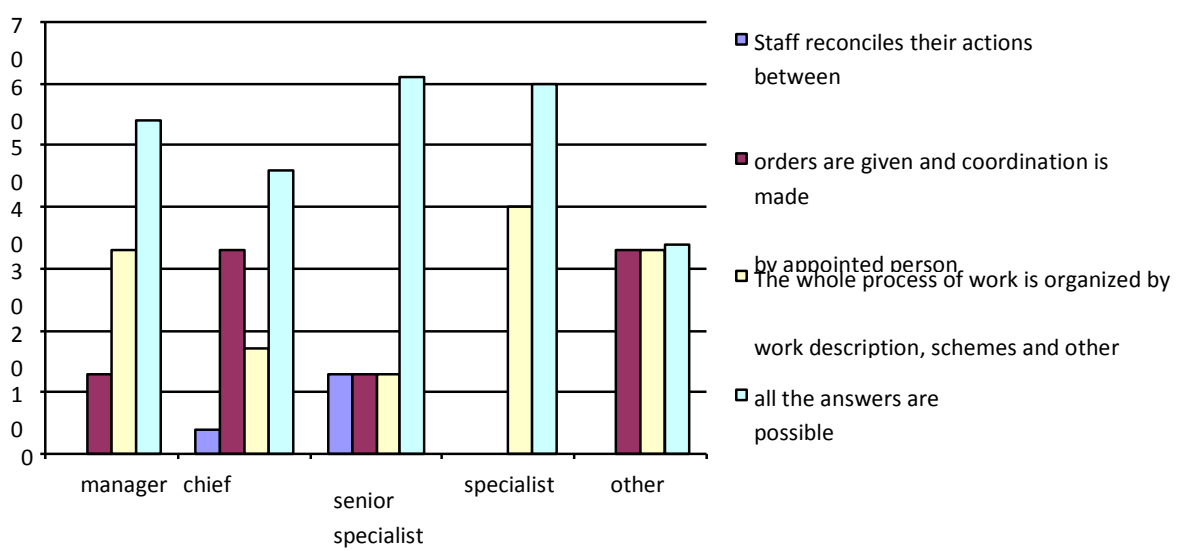

It follows that in the administration more common coordination methods are the standardization of procedures and individual orders. Using the method of working procedures, it is followed by work descriptions and documents reglamenting performance. Therefore it is very important, that these documents would be properly prepared and work position be fitted. Choosing individual orders by appointed person as a coordination method it is important to take into account person's ability to see the whole process of work as unit, and the knowledge of each member's abilities and actions.

\section{Conclusions}

Work organization combines four elements: the division of labor, creation of organizational management structure, hierarchical setting, and coordination.

The division of labor designed to break down the task into its components. It simplifies the tasks; employees become responsible not for the whole performance of a task, but for the part of it. The division of labor is the creation of individual jobs. Every workplace has its own tasks, rights and responsibilities, which are stated in each employee's work instructions. 
Coordination isn't addition to the division of labor; it is an integral part of the general management functions. Organizing work, supervisors coordinate the whole process by dividing it into smaller operations, through job instructions, schedules, procedures specifications and other documents, reg lamenting the work results. There are four coordination methods: co-ordination, standardization of qualifications, work procedures and norms, coordination of individual orders.

Conducted empirical analysis revealed that Job descriptions should be reviewed and adjusted as some of the employees' work does not provide the descriptions or an employee performs not all of the work that is described. All work should be enriched and extended in order to avoid monotony. This way worker would be given more autonomy. In job descriptions there should be more specific indicators, which rates performance, this would ease the work of managers and would make clear for employees what is expected of them. In order employees to function properly, they must be given all the authority to carry out the tasks. Each member of the organization must be familiar with the job description and the department regulations. These documents are helpful for the organizational unit to understand their purpose and location in the entire organization. Unit regulations must be made accountable because it helps managers to control and coordinate the actions of their departments.

\section{References}

1. Bakanauskas A. and others. Management of Organizations. - Lithuania: Vytautas Magnus University 2011. - 432 p. - ISBN 978-9955-12-738-3

2. Bea F. X., Haas J. Strategisches Management. Germany: Ebner\&Spiegel, Ulm, 2005. - 601 p. - ISBN 3-8252-1458-3

3. Butkus F. B. Managment for Everyone. - Vilnius: Eugrimas, 2008. - 165 p. - ISBN 978-9955-790-17-4

4. Choi, T., Hong Y. (2002). Unveiling the structure of supply networks: case studies in Honda, Acura, and DaimlerChrysler // Journal of Operations Management. Vol. 20 (5)

5. Danese, P. (2006). Collaboration forms, information and communication technologies, and coordination mechanisms in CPFR // International Journal of Production Research. 44(16)

6. Fayol H. Administration Theory and Practice. Vilnius: Eugrimas, 2005. - 135 p. ISBN 9955-501-91-X

7. Ginevičius. R., Sūdžius V. Theory of Organization. Vilnius: Technika, 2008. - 328 p. - $\quad$ ISBN 978-9955-28-150-4. http://www.ebooks.vgtu.lt.skaitykla.mruni.eu/pdfreader/organizacij-teorija [Žiūrèta 2012-0609] 
8. Little B. A new spirit for fostering organizational success // Human resource management international digest. - Emerald Group Publishing Limited, 2012, vol.20, No 4, p. 40-44. - ISSN 0967-0734

9. Malone, T. (1987). Modelling coordination in organizations and markets // Management Science. Vol. 33 (10)

10. Marcinkevičiūtè L., Žukovskis J. Theoretical and practical aspects of the management. Akademija, 2007. - 95 p. - ISBN 978-9955-448-94-5

11. Martinkus B. ir kt. Fundamentals of Management. VŠI Šiaulių universiteto leidykla, 2010. - 484 p. - ISBN 978-9986-38-983-5

12. Mellvile, R. (2011). The Organization of Production in Dinning Iinstitutions. Marijampole: Vitae Litera

13. Misevičius V. Introduction to Business Organization. Lithuanian Academy of Physical Education, 2010. - 170 p. - ISBN 978-609-8040-14-2

14. Neverauskas B., Rastenis J. Fundamentals of Management. Kaunas: Technologija, 2001. - 143 p. - ISBN 9986-13-802-7

15. Papšienè P. Viešojosektoriausreformospoveikisžmogiškųjųištekliųvadybai // Management theory and studines for rural business and infrastructure development. Šiauliųkolegija, VilniausGediminotechnikosuniversitetas, 2010. - Nr. 20 (1). - ISSN 18226760 .

16. Paunskienė J. and others. Business Basics. Vilnius: Technika, 2011. - 184 p. - ISBN 978-9955-28-838-1
17. Peters
B.
S.
Betriebswirtschaftslehre.
München:

OldenbourgWissenschaftsverlagGmbH, 2005. - 269 p. - ISBN 3-486-57685-2

18. Rüegg-Stürm J. OrganisationundOrganisationalerWandel. Wassen, 1994. - 397 p. ISBN 3-531-33679-7

19. Seifert, D. (2003). Collaborative Planning, Forecasting and Replenishment: How to Create a Supply Chain Advantage. - New York: AMACOM

20. Simon H. DasGrosseHandbuchderStrategiekonzepte. Frankfurt/Main: CampusVerlagGmbH, 2000. - 431 p. - ISBN 3-593-36410-7

21. Schreyögg G., Koch J. Wiesbaden: GWV FachverlageGmbH, 2007. - 461 p. ISBN 978-3-8349-0376-1

22. Stoner J. A. F. and others. Management.Printing and Information, 2005. - 662 p. ISBN 9986-850-30-4

23. Stoškus S., Beržinskienė D. Managment. Kaunas: Technologija, 2005. - 272 p. ISBN 9955-09-860-0

24. Thompson D. J. Organizationsinaction. SocialScience Bases of Administrative Theory. NewBrunswick: McGraw-HillBookCompany, 2007. - 192 p. - ISBN 978-0-76580991-9

25. Vanagas P. Work Organization, rationing and pay for work. Kaunas: Technologija, 2009. - 385 p. - ISBN 978-9955-25-609-0 
26. Васильев Ю. В. идр. Практикум по теории управления. Москва: Финансы и статистика, 2007. - 304 стр. - ISBN 978-5-279-02984-6

27. Лукичёва Л. И. Управление персоналом. Москва: Омега - Л, 2007. - 264 стр. ISBN 978-5-365-00639-3

\section{About the Authors:}

Ramūnas VANAGAS - Institute of Management Associate Professor, PhD, Department of Policy and Management, Mykolas Romeris University.

Janina STANKEVIČ - Master student of Mykolas Romeris University. 